\title{
New observations on Saturnella saturnus (Steinecke) Fott: the first British record of a little-known enigmatic 'green' alga
}

\author{
Christopher F. Carter ${ }^{1 *}$, Jeannie M. Beadle ${ }^{2}$, David M. John ${ }^{3} \&$ \\ Lee E. Brown²
}

${ }^{16}$ Church View, Wootton, Northampton, NN4 7LJ, UK

${ }^{2}$ School of Geography \& water@leeds, University of Leeds, Leeds, West Yorkshire LS2 9JT, UK

${ }^{3}$ Department of Life Sciences, The Natural History Museum, Cromwell Road, London SW7 5BD, UK

\section{With 16 figures and 1 table}

\begin{abstract}
Saturnella saturnus was discovered in March 2014 in open-water pools on blanket peatland at the Moor House - Upper Teesdale National Nature Reserve, straddling Cumbria and County Durham in NE England. This is the first record for the British Isles of a little-known alga recorded previously only from a few peat bog areas, mainly in mainland Europe. The literature is reviewed and new observations presented on its morphology and reproduction based on LM examination of living cells. New observations on the chloroplast structure and cytoplasmic inclusions (especially oil droplets) are discussed in relation to the findings of earlier studies. Doubt attaches as whether it is a chlorophyte or a xanthophyte and the identity of small spherical inclusions been frequently interpreted as autospores. It occurs in Upper Teesdale in pools that are small, relatively newly formed and mostly well-oxygenated. Also discussed is its relationship to Trochiscia, another coloniser of peatland pools.

Photographic images are presented for the first time and comments made on its ecology in the context of blanket bog conservation projects and apparent rarity.
\end{abstract}

Key words: Saturnella, peat bog, blanket bog, Sphagnum, Chlorellales, Teesdale

\section{Introduction}

The enigmatic single-celled green alga Saturnella saturnus (Steinecke) Fott (Chlorophyta, Chlorellales) has attracted interest on account of its startling similarity to the planet Saturn. The characteristic thickened ring of wall material around the equator

*Corresponding author: chris.carter@6cvw.freeserve.co.uk 


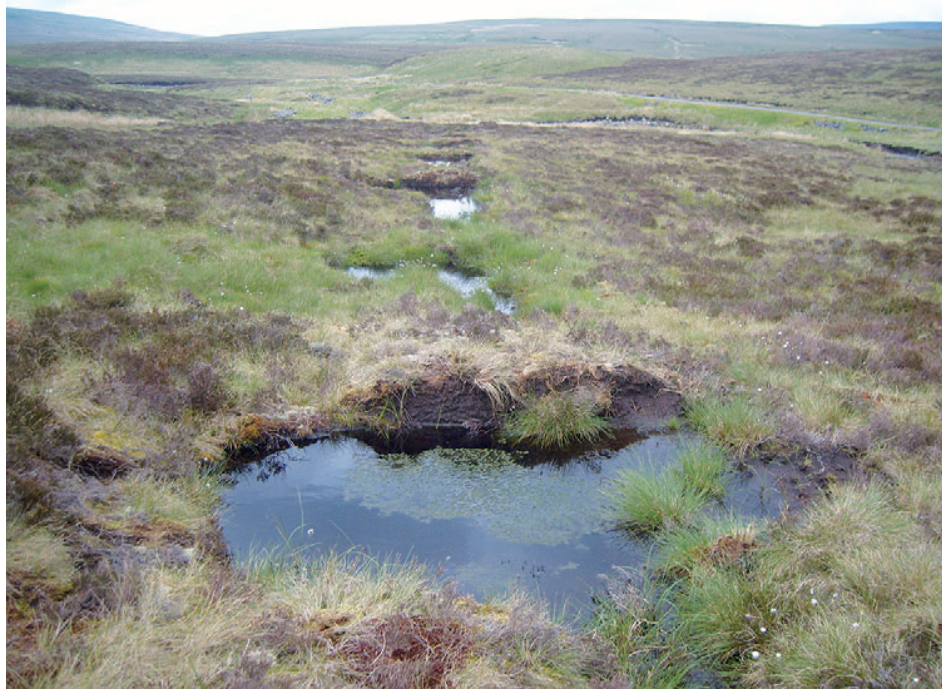

Fig. 1. A series of pools formed behind peat-turf dams in a blocked drainage ditch at Moor House - Upper Teesdale NNR, Cumbria.

readily distinguishes it from other little-known unicellular species belonging to the green (Chlorophyte) or yellow-green (Xanthophyte) algae associated with peat bogs frequently dominated by the moss Sphagnum. This species of Saturnella was first discovered in the British Isles in material collected during March 2014 from artificially created pools on Moor House - Upper Teesdale National Nature Reserve, Durham, England (Beadle et al. 2014).

This paper presents the findings of observations of this new record based on samples collected between March and June 2014 and in June 2015. Our findings are discussed and compared to the sometimes conflicting accounts in the earlier literature on the taxonomy, morphology, life history and habitat of what remains a little-known genus.

\section{Literature review}

Early last century Steinecke (1916) described a new species of Protococcus (Protococcus saturnus) based on material from Kalingrad Oblast (between Lithuania and Poland). The species was so named because it possessed a thickened ring around the equator of the spherical cell, and so resembled the planet Saturn. Figure 2A is one of Steinecke's line drawings and selected illustration of Saturnella in publications by Fott $(1960)$ and Skuja $(1959,1976)$ are shown in Figures 2B-D (see below). The material was reported in bogs, "waterside mud" in ditches with Batrachospermum and was considered by Steinecke (1916, p. 74) to be part of an "algal community of a typical moorland type". It was next recorded by Mattauch \& Pascher (1936) who created the 

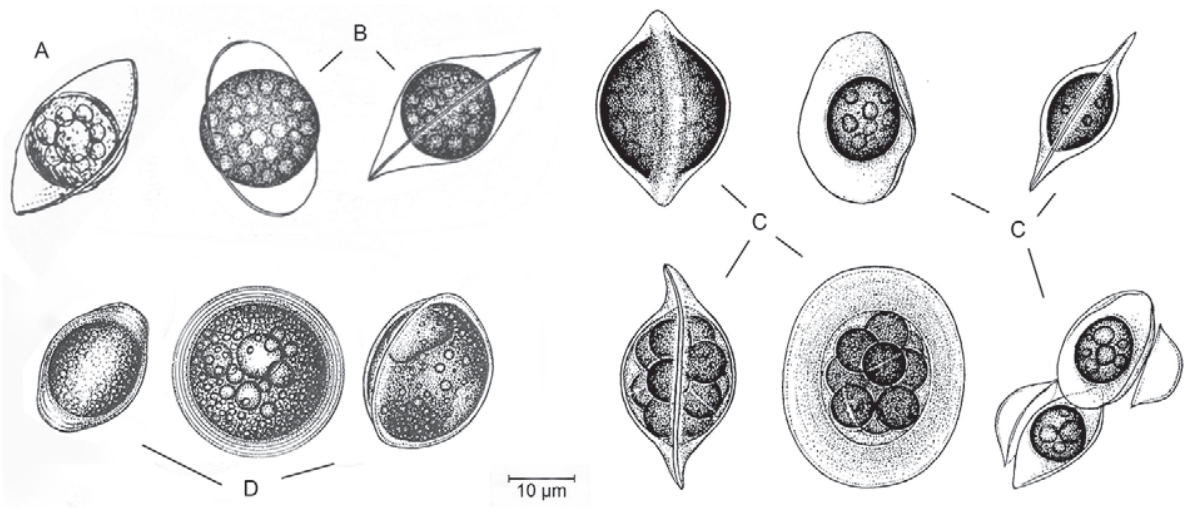

Fig. 2. Line drawings of Saturnella saturnus: A (Steinecke 1916), B (Fott 1960), C (Skuja 1959) and D (Skuja 1976).

new genus Saturnella (type S. elegans) since uncertain as to whether their material was identical to Protococcus saturnus. Saturnella was described as consisting of single, spherical cells having a fold on the equator, several plate-like chloroplasts, dense oil droplets obscuring the cell contents and reproducing by autospores. The genus was considered to be a 'heterokont' alga (presumably xanthophyte) and the authors acknowledged the difficulty of trying to interpret its cell contents. Pascher (1939, p. 909) considered it "with reservation" to be a coccoid green alga and again mentioned its presence in Bohemian Sphagnum bogs whose $\mathrm{pH}$ ranged from 4.6 to 6.8.

Skuja (1959) subsequently examined rich collections from the Uppland province of Sweden of what he believed to be material identical to Steineck's Protococcus saturnus and provided more detailed descriptions of the cells. Skuja was of the opinion that there were two opposed chloroplasts, one at each pole and these were separated by a hyaline zone. His drawings also show autospores in the larger cells with each possessing a characteristic ring-like thickening. Rather surprisingly, Skuja, appeared to have been unaware of the Mattauch \& Pascher (1936) investigation and transferred $P$. saturnus to a Discocytis (type species Discocytis saturnus), a new genus he created and placed it in the Order Oocystales.

The early confusion surrounding Protococcus saturnus Steinecke was resolved by Fott when in 1960 he reported the discovery of a "noteworthy" alga in a moor in South Bohemia. Fott considered it to be very rare since having personally visited many promising sites and yet only discovered it on two occasions. Tellingly, Fott admits to having been unable to determine details of the cell contents and "now understood" why Pascher \& Mattauch (1936) had also been unable to do so. Despite these difficulties Fott (1960) had no doubt that the earlier authors were dealing with the same alga because of the unique form of the cell. He therefore transferred Steineck's Protococcus saturnus to Saturnella thus the new combination Saturnella saturnus (Steinecke) Fott. He also transferred to the genus Protococcus corticola Skuja thus Saturnella corticola (Skuja) Fott. 
Further information on Saturnella was published posthumously by Skuja (1976) and was based on an examination of formalin preserved material collected by the Swedish Professor H. Osvald in 1951 and 1952 from moors in New Zealand. Some of the New Zealand localities mentioned have been questioned by Cassie (1984) but "Swampy Hill Pond" (near Dunedin) seems to be the type of locality from where it might be expected to be discovered based on what is known of its European distribution. The vegetative cells of the New Zealand material were somewhat smaller than the swollen, presumed spore-containing cells reported elsewhere, although the rounded bodies in the cells were not observed with an equatorial thickening and yet these were interpreted as autospores. Skuja implied that the double parietal chloroplast was only weakly developed and described many oil bodies or photosynthetic products ("assimilats"), both large and small. Doubt inevitably exists as to whether the New Zealand material is the same as the European material and whether the small spherical bodies should be considered autospores since not possessing an equatorial wall thickening.

Another interesting account of S. saturnus is one by Matula (1973) who discovered it in a small shallow depression in a blanket peat bog in Poland, the pool containing Sphagnum on the bottom and having a $\mathrm{pH}$ of less than 4. Matula's figures show the familiar discoid shape of younger and older cells, but now the equatorial thickening is described (p. 476) as scarcely evident and the cells to contain "numerous greenish-yellow spherical formations".

A more recent account of Saturnella comes from The Netherlands where Kouwets (1980) recorded it from a very low nutrient, unpolluted, highly oxygenated pool in the remnant of an ancient peat bog (near Saasveld) that had been subject to cutting but later restored. Data are provided on water chemistry but few details are given on cell structure. Kouwets (pers. comm.) has not seen it subsequently, although he noted the presence of Trochiscia in the same pool.

\section{Background}

Blanket bogs are a globally threatened habitat although well represented in some parts of the British Isles owing to the cool, oceanic climate (Lindsay 2010). Many northern bogs are home to permanent, open-water pools characterized by low $\mathrm{pH}$, low levels of primary production and nutrients although often with a high concentration of dissolved organic matter. In the last twenty years or so, the array of naturally occurring bog pools in the British Isles has been supplemented by the creation of many thousands of pools using the land management technique known as drain-blocking. In the past many peat bogs were drained with the aim of 'improving' the land for cattle grazing and enhancing game bird abundance, but recognition of the wider environmental impact of this practice has led to a significant drive to rewet peatlands by blocking drains in order to recreate open water pools (see Ramchunder et al. 2009). For example, an estimated $>500,000$ new pools have been created in the North Pennines alone over the last 15-20 years (Alistair Lockett, pers. comm.) The dimensions of these new 
pools are constrained by the size and shape of the drain in which they form, but generally they are small with a mean depth of less than $50 \mathrm{~cm}$ and a surface area of less than $2 \mathrm{~m}^{2}$. The rewetting of the peatlands is an attempt to restore them to a fully functional, revegetated state and has led to a number of research studies on the effects of this practice on peatland carbon cycle processes (Holden et al. 2007). However, little is known about the ecological status of these artificially created peatland pools, especially with regards to the algal communities (Beadle et al. 2015). One recent study in Scotland reported a loss of desmid diversity in drained peatlands which slowly recovered after drain blocking (Goodyer 2014).

\section{Materials and methods}

\section{Sampling}

Samples were collected from drain-blocked pools at six upland blanket bog sites across the North Pennines and Yorkshire Dales, but Saturnella saturnus was discovered to be sparsely distributed in just one pool complex at the Moor House - Upper Teesdale National Nature Reserve (Fig. 1). The vegetation at all sample sites was typical of blanket bogs and therefore largely dominated by ling heather (Calluna vulgaris), cotton grass (Eriophorum spp.), Sphagnum and pleurocarpous mosses such as Pleurozium schreberi.

Five Moor House pools were sampled on several occasions between March and June 2014 and again in June 2015. Two sampling methods were used: (1) collection of free-floating algae in $50 \mathrm{ml}$ plastic tubes with screw caps, and (2) collection of bryophyte material in twist-lock bags. Saturnella was discovered in small numbers using these methods but it was decided to concentrate on the bryophyte sampling method because free-floating algae were not always present. Each pool sampled was measured along its long axis and short axis and mean depth and perimeter were recorded. A Hach HQ30d handheld probe was used to measure $\mathrm{pH}$, electrical conductivity $\left(\mu \mathrm{S} \mathrm{cm}^{-1}\right)$, dissolved oxygen $\left(\mathrm{mg} \mathrm{l}^{-1}\right)$ and water temperature $\left({ }^{\circ} \mathrm{C}\right)$. Water samples were collected for analysis of total nitrogen (TN) and total phosphorus (TP), silica (Si) and dissolved organic carbon (DOC).

\section{Sample preparation}

Algal samples were stored immediately after collection at about $4{ }^{\circ} \mathrm{C}$ and examined within a few days. They were examined initially using a low power binocular microscope and macroscopic forms were separated from microscopic forms. Samples were then filtered through a nylon gauze filter of about $0.5 \mathrm{~mm}$ pore size and allowed to settle overnight in tall glass vessels. The sedimented algae were examined using brightfield, phase contrast and polarised light microscopy. Many algae were photographed for later metric analysis, especially Saturnella and possibly related forms. 


\section{Results}

\section{Cell morphology}

The cells of Saturnella were readily recognized because of their characteristic appearance and by careful manipulation a number were examined in different aspects, from edge-on through to face on (Figs $3 \mathrm{a}$ and $3 \mathrm{~b}$ ). Seventy cells were measured for major
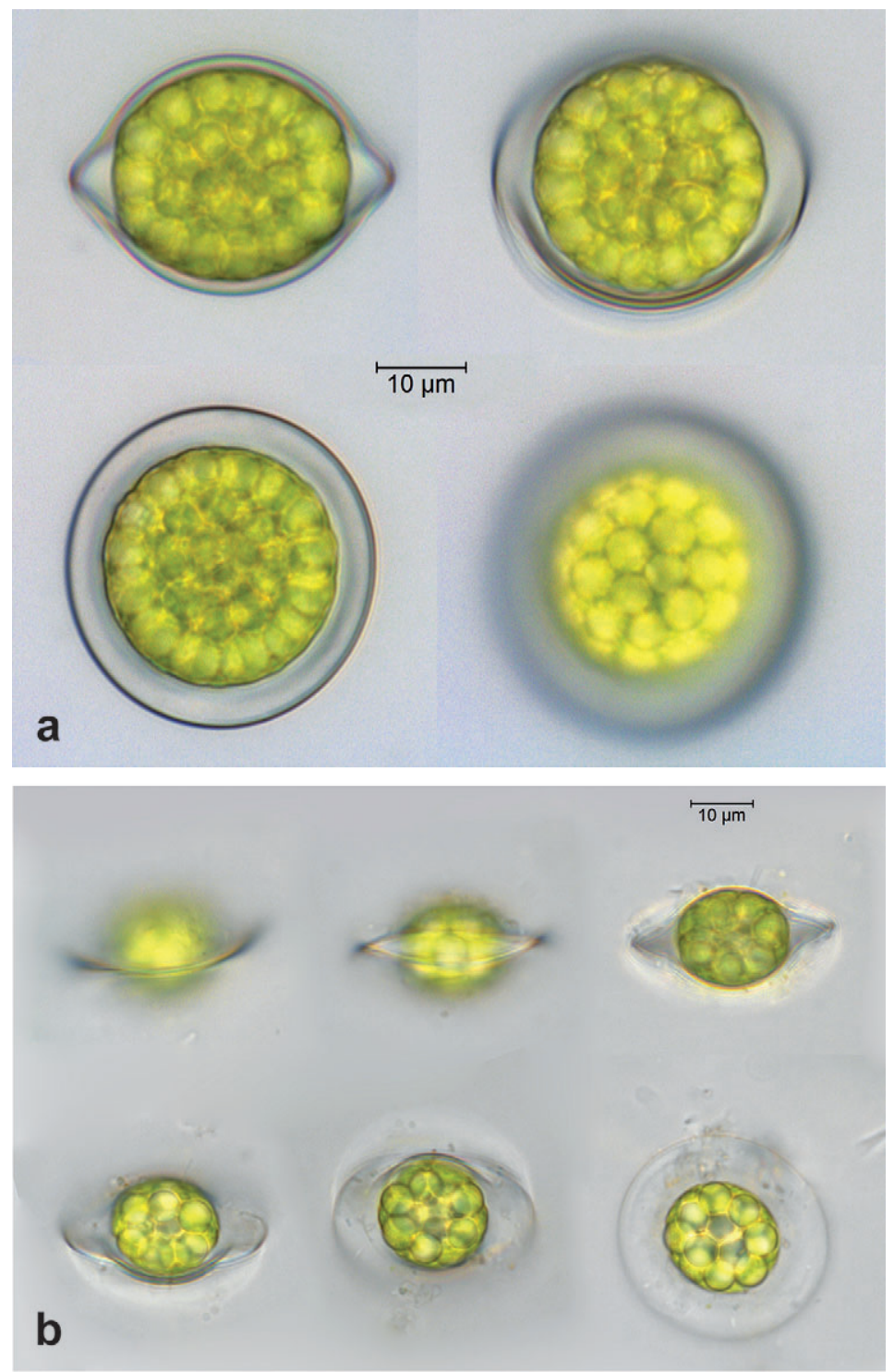

Fig. 3a and b. Two examples of typical Saturnella saturnus cells viewed from different angles and at different focus points. 


\section{Cell diameter-inner}

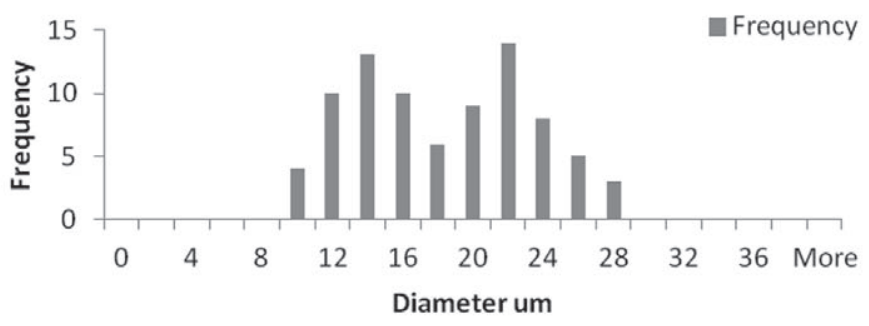

\section{Max outer diameter (usually of ring)}

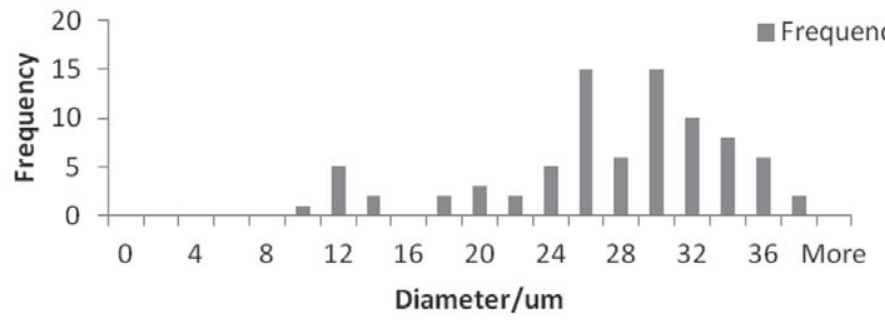

\section{Ring diameter/cell diameter}

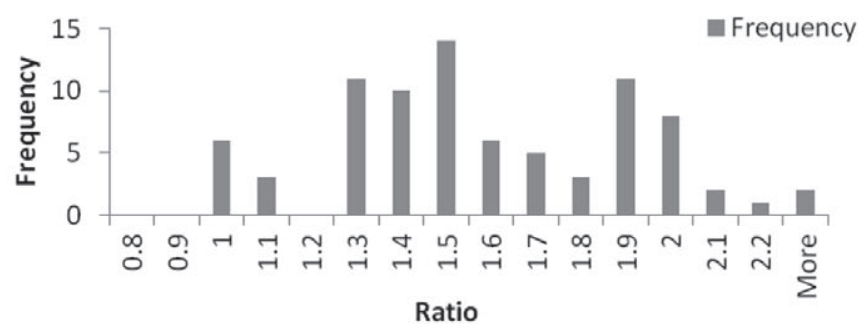

\section{Max globule diameter in cell}

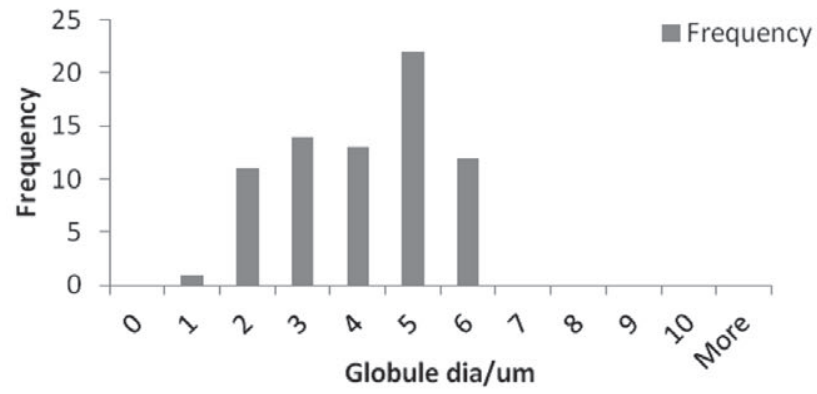

Fig. 4. Histograms showing size distributions of Saturnella saturnus cells and spherical bodies or globules (oil droplets). 


\section{Carter, Beadle, John \& Brown}
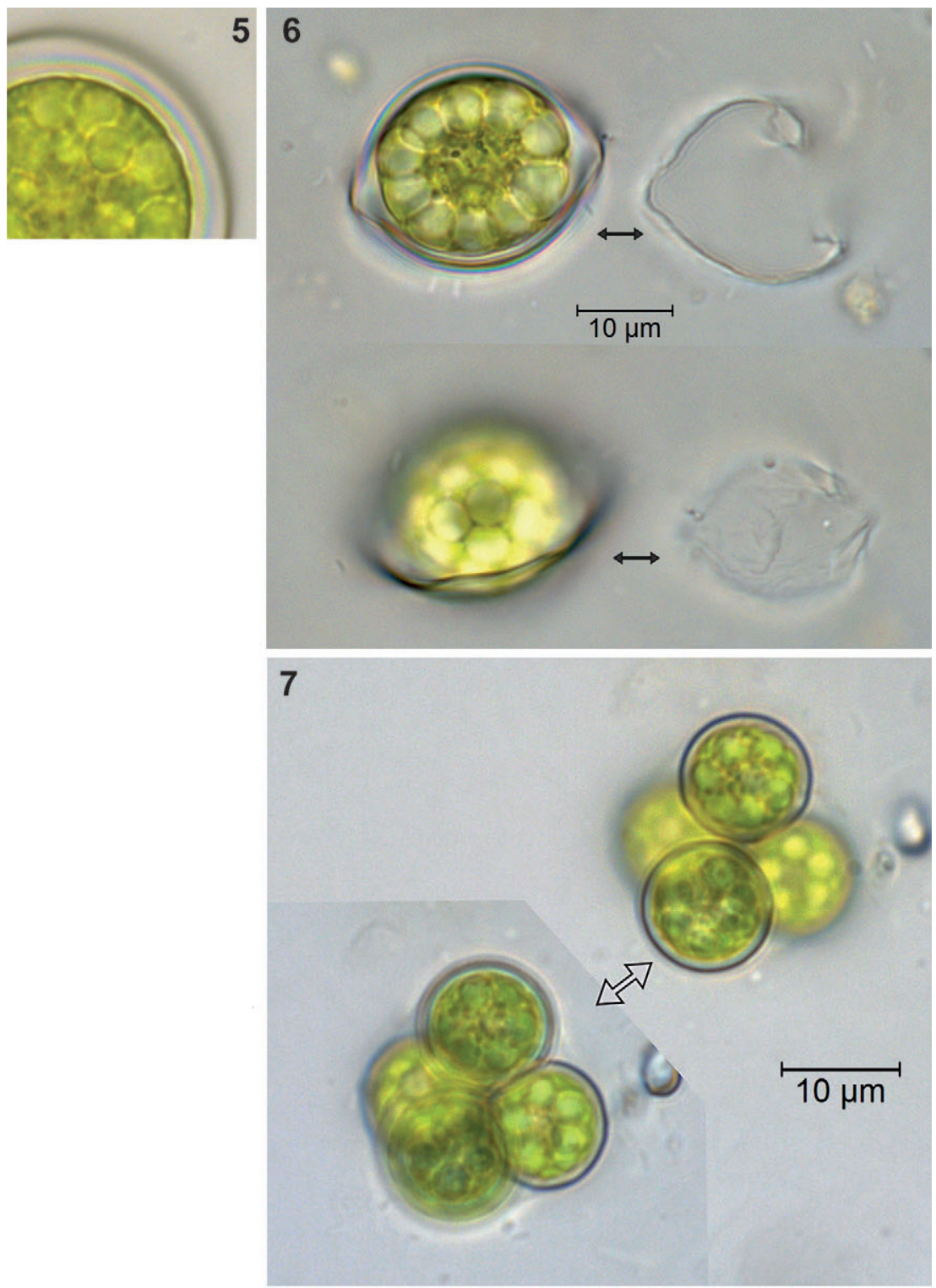

\section{8}
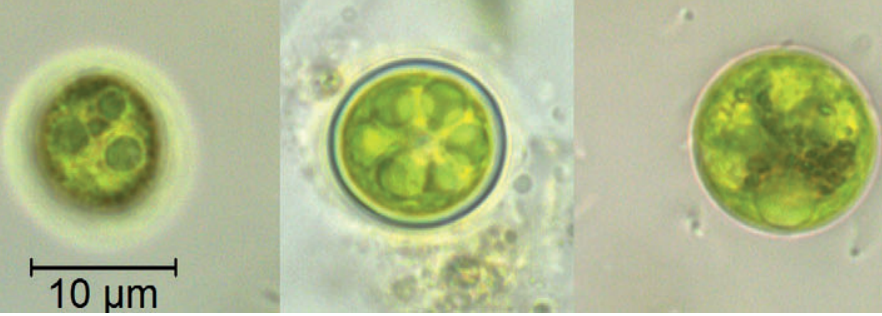
(with ring) and minor (without ring) diameters as well as the typical sizes of any spherical cellular inclusions (Fig. 4). The rings appear to be finely striated and diffraction patterns were visible when viewed at certain angles (Fig. 5) although it cannot be discounted that this might be a prismatic effect. Remnants of the cell walls were visible, (Fig. 6) as would be expected following spore release but no obvious autospores (miniatures of the spore-mother cells) were discovered since none of the released cells (see Figs 7 and 8, for example) had an equatorial thickening. Several types of cell were observed, presumably representing cells of different ages following release from the mother cell. Larger cells contained many spherical bodies and an indeterminate chloroplast structure. Some smaller cells contained opaque bodies filling the cell and these are probably chloroplasts (Fig. 9)

\section{Spherical bodies}

Practically all the cells, even the smaller ones, contained spherical bodies of an indeterminate colouration and frequently were obscured by the other cellular components. These bodies appeared to have no internal structure under the LM and are probably oil droplets as described by Skuja (1959), Mattauch \& Pascher (1936) and others. They are mostly of a uniform diameter at a given radial distance from the cell centre and tend to be larger towards the periphery of the cell. The close-packing of these spheres and the slight lensing-distortion (created by the envelope) sometimes give the illusion that they have rings (Fig. 10). In one case a splitting cell was observed in which there were irregularly shaped vacuoles (Fig. 11) resembling those in one of the cells drawn by Skuja (1976, pl. II, fig. 18; shown as Fig. 2D). Sometimes spherical bodies were observed forming within a cell by rearrangement and partitioning of its contents (Fig. 12). Fungal chytrid-like attacks were frequently observed and some of the internal structures might be caused by the disruption of the cellular contents by these parasites.

\section{Chloroplasts}

A number of small cells were observed in which a dense chloroplast apparently filled the internal volume (Fig. 9), but in none of these did the chloroplast appear to be divided into two halves with one at each pole. Cells containing dense spherical bodies (oil droplets) frequently also contained a somewhat disrupted chloroplast. At one extreme these 'chloroplasts' took the form of a delicate ribbon (Fig. 13) weaving around the oil droplets and having thickened sections; iodine staining could not confirm the presence of starch but small pyrenoids might have been present. At points where the

Fig. 5. Diffraction pattern evident from rim of a cell. Fig. 6. Mother cell remains at different focus points. Fig. 7. Typical small cells with rings and no oil droplets. Fig. 8. Cluster of small cells within the sample resembling Saturnella saturnus but with no ring-like wall thickening although containing prominent spherical bodies believed to be oil droplets. 


\section{Carter, Beadle, John \& Brown}
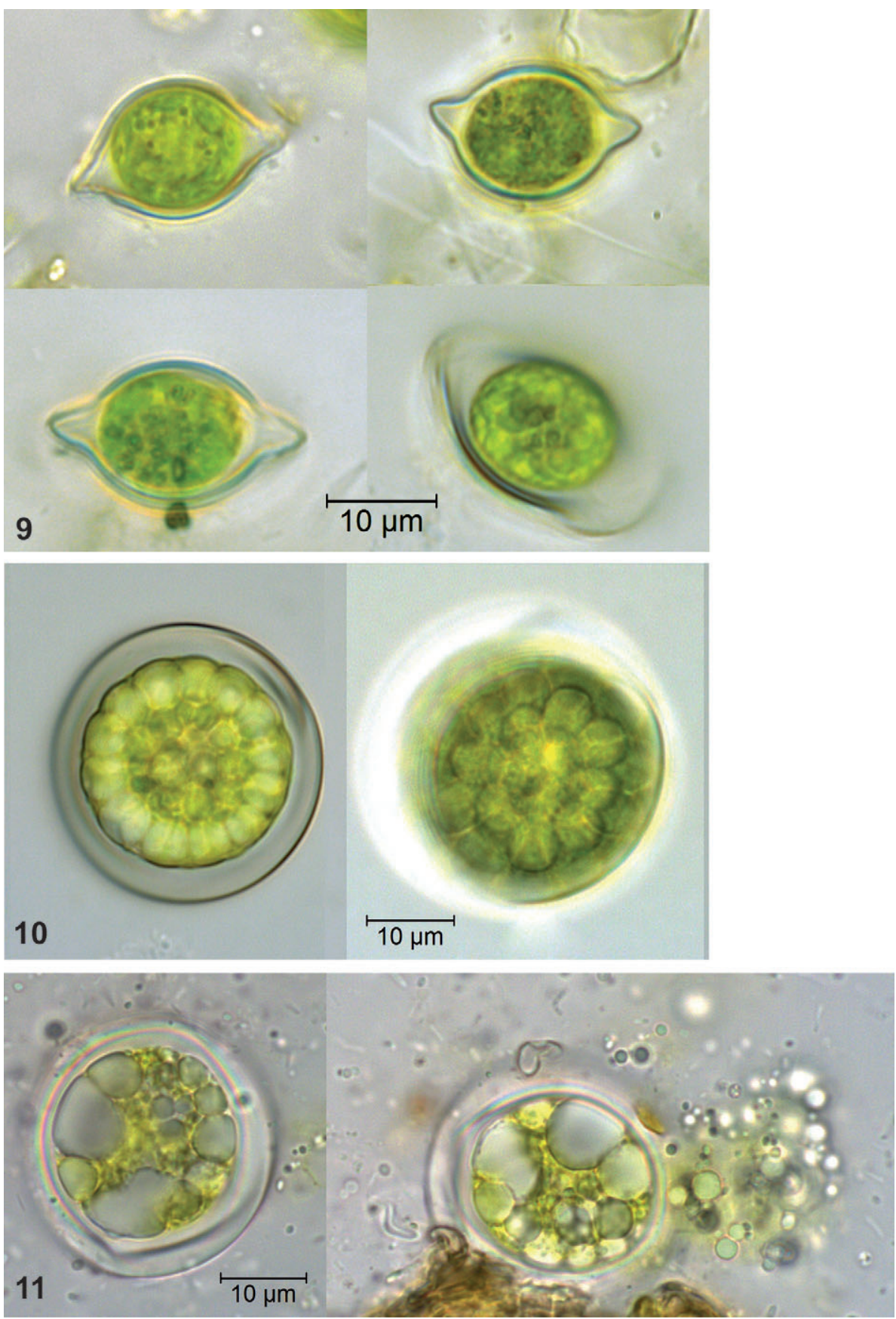
ribbon passed in front of the oil droplets the illusion of a ring was also created. At the other extreme, many small, regularly arranged granular and dark green bodies (Fig. 14) were seen around the spherical oil droplets. These were arranged in a regular pattern giving the entire cell a light green colouration and might be the remains of the thickened areas mentioned above. Chloroplast-like structures in the form of small angular plates were also seen (Fig. 15) as were more elliptical structures (Figs 9, 16), optically seeming like tori with a colourless centre. Other small pale yellow-green bodies were of frequent occurrence near damaged or splitting cells but their nature also remains unknown.

\section{Refractory inclusions}

Cells examined under crossed polaroid filters revealed the cell wall to be weakly refractory (apparent at the thicker sections) and also present were many very small refractory particles exhibiting rapid Brownian motion. These particles are apparently concentrated towards the centre of the cell but it cannot be discounted that this might be partly an optical illusion. The most likely origin would seem to be clay-like irregularly crystalline silicate minerals.

\section{Ecology}

Table 1 summarises the physical and chemical analyses of the pools in the wider study, with Saturnella found with certainty only at Moor House. All pools were characterised by having low nutrient levels, low electrical conductivity, low concentrations of silica, relatively high levels of DOC (dissolved organic carbon) and a relatively low $\mathrm{pH}$. The water chemistry of these pools is broadly similar to that described by Kouwets (1980) in the Netherlands.

All the pools sampled were relatively recently formed (15 to 18 months old) at the time of sampling. Larger filamentous green algae were infrequent (e.g. Spirogyra, Oedogonium, Ulothrix) in these pools as were Saccoderm desmid communities that are typical of many Sphagnum dominated bog pools. Common in these pools was Gloeocystis vesiculosa, which is often an early colonizer (see John et al. 2002, p. 450), very gelatinous colonies of Mesotaenium macrococcum (usually a common subaerial form), a wide range of single-celled motile species and various 'palmella' stages. Diatoms were sparse reflecting the low silica levels. Eunotia spp. and Frustulia saxonica were infrequent whilst at the other sample sites species of Achnanthidium, Cyclotella, Cymbella and Pinnularia were present suggesting less pristine conditions.

Fig. 9. Cell in which aligned superimposed globular bodies (oil droplets) create the illusion of small rings (and hence of autospores). Fig. 10. Damaged cell showing escape of contents and large vacuoles including oil droplets. Fig. 11. Typical examples of presumed released spherical bodies containing oil droplets. 
72 Carter, Beadle, John \& Brown
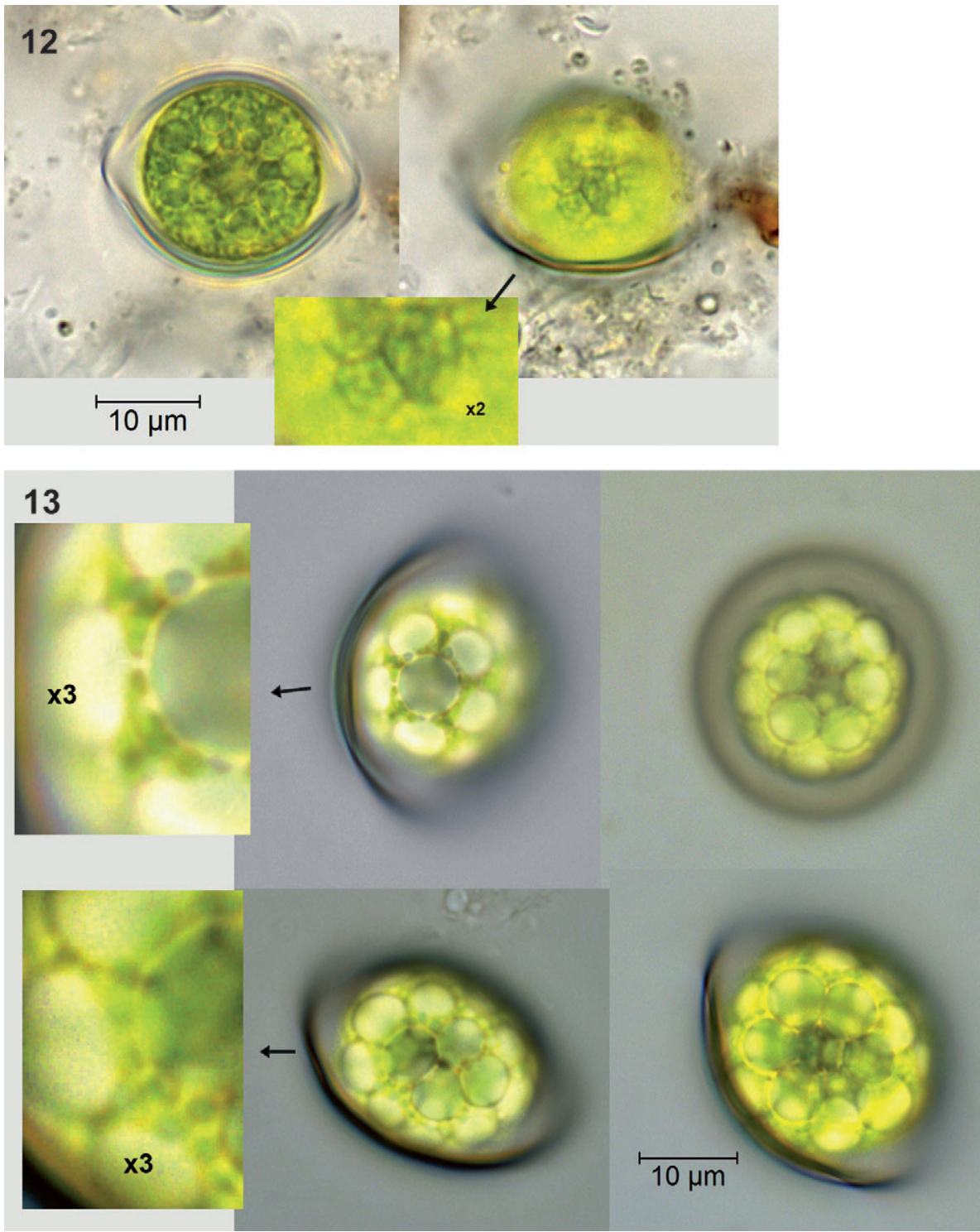

Fig. 12. Cell showing partitioned cell contents. Fig. 13. Ribbon-like chloroplasts among oil droplets and showing thickened areas. 

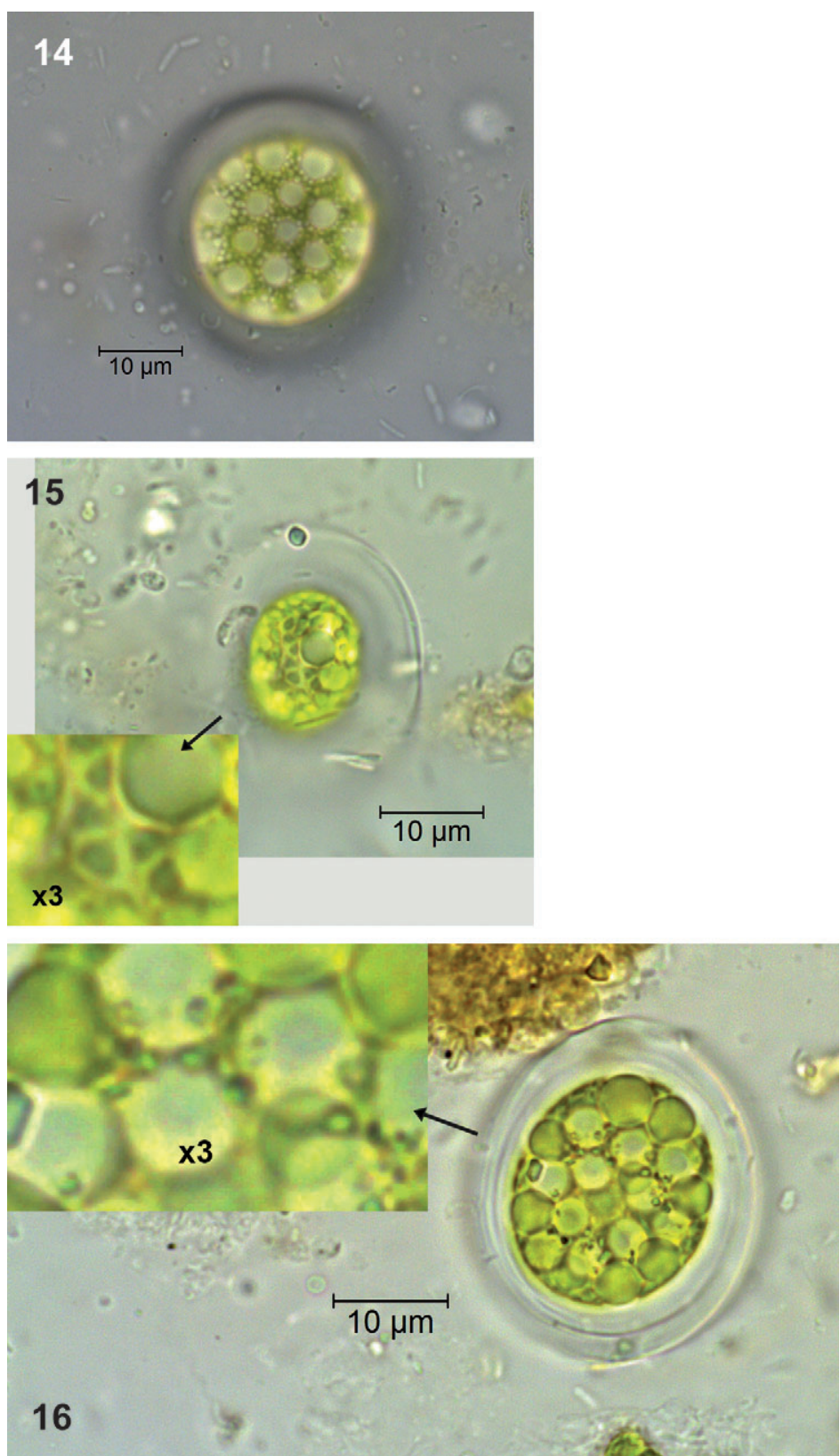

Fig. 14. Regular arrays of small chloroplast or pyrenoid-like structures. Fig. 15. Angular chloroplast-like structures in a cell, with enlarged detail. Fig. 16. Chloroplast-like structures having the form of small tori. 
74 Carter, Beadle, John \& Brown

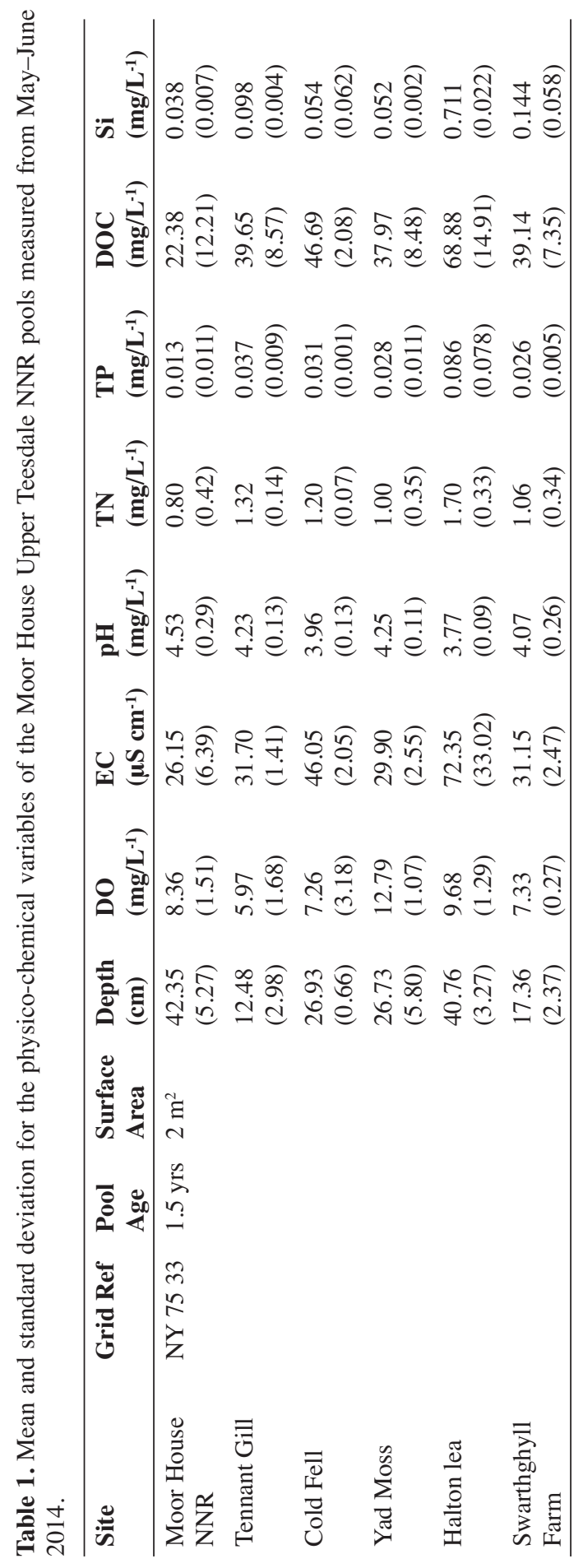




\section{Discussion}

The rarely reported alga Saturnella saturnus is a component of the algal flora of some artificially created peat pools in the North Pennines.

The Saturn-like ring of thickened wall material is the most characteristic feature of this species although not possessed by all the cells. Some smaller cells without the ring are almost impossible to distinguish from those of Trochiscia whose coccoid autospores do not produce their characteristic ornamentation when first released. Cell diameter measurements (Fig. 4) show the thickened ring to be up to twice the diameter of the spherical part of the cell, but more commonly is about 1.5 times greater. The size distribution of the spherical part of the cell is arguably bimodal perhaps indicating the greater preponderance in larger cells of the spherical inclusions discussed below.

The form of the chloroplast changes as cell size increases. In smaller cells the chloroplast is dense and occupies most of the cell volume, but in none of the cells examined was the chloroplasts double as described by Skuja (1959). In larger cells it is difficult to interpret the chloroplast structure because of the presence of many spherical and structureless bodies that are probably oil droplets. The chloroplast in these cells becomes disrupted by these bodies and forms delicate ribbons weaving among them. At a later stage, thinner sections of the ribbon disappear or become transparent. Thicker sections of the ribbon-like fragments of the original chloroplast apparently become regular arrays of small dark green bodies.

Some of the observations suggest that the cell contents become partitioned into subunits and these become released as small cells. Only Skuja (1959) has described miniature cells with Saturn-like rings and then only in what he regards as "exceptionally good' material. Reproduction remains enigmatic and inconclusive with no convincing evidence that it is an autospore-producing alga. Doubt concerning the presence or absence of spores and the difficulty of interpreting the LM observations of its cellular contents makes it impossible to be certain of the taxonomic position of Saturnella.

The cells of Saturnella with an equatorial wall thickening are very distinctive but in its absence then it might have been overlooked in the past in collections of peatbog algae. Common algae in such bog pools include the 'palmella' stages of chlamydophycean algae, saccoderm desmids and also other green algae such as Asterococcus, Coenococcus, Chlorella, Trochiscia and Planktosphaeria gelatinosa. It is possible that smaller cells, without an obvious equatorial ring-like wall thickening, might be mistaken for the latter two taxa. Certainly, cells without an equatorial thickening might be mistaken for those of Trochiscia which have yet to develop an ornamented wall following release as autospores. If the distinctive ring-like thickening were present then it seems unlikely that Saturnella would be mistaken for any other alga. It is unlikely to have been overlooked if present in established pools or natural bog pools since these habitats are frequently sampled by those searching for desmids. One reason it might have been overlooked in the past is because it is seemingly con- 
fined to young or seasonally-flooded pools in boggy areas, such as the recently created ones studied here. Other algae present in these pools include known 'early colonisers' such as Gloeocapsa and normally subaerial algae such as Mesotaenium, perhaps even soil algae including Planktosphaeria. All of these organisms are to be regarded as indicators of damp and/or seasonally-inundated depressions, and from our study appear to be pioneer colonisers of pools formed relatively soon after peatland drains are blocked.

Further work on Saturnella is required including an ultrastructural investigation (perhaps alongside the much commoner Trochiscia), culture-based studies and eventual a genomic investigation involving analysing sequence data, if progress is to be made understanding the biology and taxonomic position of this structurally unusual and rare bogland alga.

\section{Acknowledgements}

Thanks go to the following: Dr. E. Haworth (FBA, Windermere) for providing details of Saturnella images held in the Fritsch collection and informing us that several algal texts incorrectly used the name Saturnella saturna, and Prof M.D. Guiry for informing us that 'saturnus' is a properly a noun rather than an adjective and remains masculine (if an adjective then saturna). One of us (JB) was supported by a NERC studentship (NE/J50001X/1) with CASE support from the RSPB. We would like to thank the anonymous referee for making helpful and constructive comments on the manuscript and for suggestions on further studies involving drawing on the expertise of other specialists.

\section{References}

Beadle, J., Brown, L.E., Carter, C.F. \& Holden, J. (2014): Saturn has landed on the moors: first record of Saturnella saturnus from the British Isles. - Freshw. Biol. Assoc. News 63: 2-3.

Beadle, J.M., Brown, L.E. \& Holden, J. (2015): Biodiversity and ecosystem functioning in natural peat pools and those created by rewetting schemes. - WIRES Water 2: 65-84.

Cassie, V. (1984): Revised checklist of the freshwater algae of New Zealand (excluding diatoms and charophytes). Part 1. - Water and soil technical publications 25: i-xii, 1-116, i-lxiv.

Fott, B. (1960): Zur Kenntnis der Gattung Saturnella (Chlorococcales). - Nova Hedwigia 2: 273278.

Goodyer, E. (2014): Quantifying the desmid diversity of Scottish blanket mires. PhD Thesis, University of Aberdeen.

Holden, J., Shotbolt, L., Bonn, A., Burt, T.P., Chapman, P.J., Dougill, A.J., Fraser, E.D.G., Hubacek, K., Irvine, B., Kirkby, M.J., Reed, M.S., Prell, C., Stagl, S., Stringer, L.C., Turner, A. \& Worrall, F. (2007): Environmental change in moorland landscapes. - Earth-Sci. Rev. 82: 75-100.

John, D.M., Whitton, B.A. \& Brook, A.J. (eds) (2002): The freshwater algal flora of the British Isles. An identification guide to freshwater and terrestrial algae. pp. i-xii, 1-702. Cambridge: Cambridge University Press.

Kouwets, F.A.C. (1980): Floristic and ecological notes on some little-known unicellular and colonyforming algae from a Dutch moorland pool complex. - Cryptogamie: Algologie I 4: 293-309. 
Lindsay, R.A. (2010): Peatlands and carbon: a critical synthesis to inform policy development in peatland conservation and restoration in the context of climate change. - Report to RSPB Scotland, Scottish Natural Heritage, Natural England, Forestry Commission, Countryside Council for Wales, IUCN UK Peatlands.

Matuła, J. (1973): Dwa nowe dla Polski gatunki glonów: Saturnella saturnus (Stein.) Fott i Chloropteris tetragona Pasch. (Chlorococcales). - Fragmenta Floristica et Geobotanica 19: 475-479.

Mattauch, F. (1936): Ein Beitrag zur Kenntnis der Verlandungserscheinungen am Hirschberger Grossteich. - Beih. Bot. Cbl. 54B: 377-428.

Pascher, A. (1939): Heterokonten. - In: Rabenhorst, L. (ed.), Kryptogamen-Flora von Deutschland, Österreich und der Schweiz, Vol. 11, pp. 833-1092, [iii-x]. Leipzig: Akademische Verlagsgesellschaft.

Ramchunder, S.J., Brown, L.E. \& Holden, J. (2009): Environmental effects of drainage, drain-blocking and prescribed vegetation burning in UK upland peatlands. - Progr. Phys. Geogr. 33: 49-79.

Skuja, H. (1959): Über eine discoide Ausbildung der Oocystaceen. - Nova Hedwigia 1: 1-16.

Skuja, H. (1976): Zur Kenntnis der Algen neuseeländischer Torfmoore. - Nova Acta Regiae Societatis Scientiarum Upsaliensis 5, C2: 1-159.

Steinecke, F. (1916): Die Algen des Zehlaubruches in systematischer und biologischer Hinsicht. Schriften der Physikalisch-ökonomischen Gesellschaft zu Königsberg 56: 1-138.

Manuscript received July 29, 2015, accepted October 19, 2015 